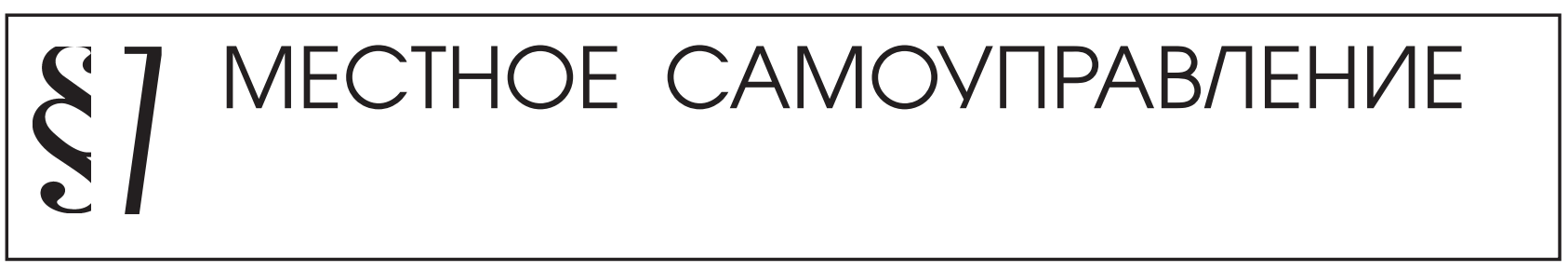

А.А. Афанасьев

\title{
МУНИЦИПАЛЬНО-ПРАВОВОЙ РЕЖИМ СЕЛЬСКОЙ ЖИЗНИ: ИСТОРИКО-ПРАВОВЫЕ АСПЕКТЫ МЕСТНОГО САМОУПРАВЛЕНИЯ СЕЛЬСКИХ ПОСЕЛЕНИЙ В РОССИИ
}

\begin{abstract}
Аннотация: Общественные отношения, связанные с осуществлением местного самоуправления сельских поселений, являются важнейшей составляющей сельской жизни как предмета правового регулирования. $B$ статье на основе анализа законодательства Российской Федерачии и научной юридической литературы исследуются исторические особенности сельского местного самоуправления. Учёт собственного российского исторического опыта правового регулирования сельской жизни важен для успешной реализачии приоритетного направления сочиально-экономической политики России по устойчивому комплексному развитию сельских территорий. Ключевые слова: общественные отночения, муниципально-правовое регулирование (муниципльно-правовой режим), сельское поселение, сельское население, сельская жизнь, местное самоуправление, устойчивое комплексное развитие сельских территорий.
\end{abstract}

$\mathrm{B}$ правовом регулировании сельской жизни местное самоуправление сельских поселений (местная власть) действует наравне с государственной властью и занимает особое место, являясь наиболее приближенной к населению. Она призвана решать на основе Конституции Российской Федерации, Федерального закона от 6 октября 2003 года № 131-Ф3 «Об общих принципах организации местного самоуправления в Российской Федерации» (далее - Федеральный закон № 131-Ф3 2003 года) самые насущные вопросы сельских жителей. Учёт собственного российского исторического опыта муниципально-правового регулирования (режима) сельской жизни, безусловно, может и должен помочь в реализации приоритетного направления социально-экономической политики России по устойчивому комплексному развитию сельских территорий.

В юридической науке и литературе признается специфика в развитии отечественного местного самоуправления в сельских поселениях, подчеркивается определенная преемственность современного муниципального права с нормами права дореволюционной России.

А.Н. Костюков подчеркивает, что «выявление и исследование самостоятельной политической, социаль- но-экономической, юридической природы городского и сельского самоуправления имеет важное теоретическое и практическое значение. Специфика организации и осуществления местного самоуправления в городских и сельских поселениях обусловливает естественное формирование подотраслей муниципального права - городского права и сельского права.

В подтверждение особой значимости для России местного самоуправления сельских поселений приведем вывод Н.Я. Данилевского. Рассматривая разнообразные институты русского общества, он особым образом выделяет сельскую общину, называя ее «неприкосновенной формой собственности», институтом, органически связанным с присущими России формами управления. ${ }^{2}$

Местное самоуправление в сельских поселениях России имеет богатый исторический опыт, насчитывающий несколько столетий. Примечательно, что в периоды кризиса государственной власти неизменно проходило его реформирование (начало семнадцатого

\footnotetext{
${ }^{1}$ Костюков А.Н. Муниципальное право как отрасль российского права: Монография. М.:, 2003. С. 181.

2 Данилевский Н.Я. Россия и Европа. М., 1991. С. 91, 492-493.
} 


\section{Политика и общество 3 (99) • 2013}

века, шестидесятые годы девятнадцатого века, начало двадцатого века, современный этап истории). В разных исторических условиях самоуправленческие начала в сельских поселениях российского общества выражались в различных формах, среди которых следует выделить наиболее устойчивые: вечевая демократия Древней Руси, крестьянское общинное самоуправление, волостное самоуправление, земское самоуправление, местные советы. Вечевая демократия - наиболее раннее проявление самоуправленческих начал на Руси. ${ }^{3}$ Ее развитие происходило в период перерастания родоплеменных объединений в добровольные общности самостоятельных хозяев (крестьянских дворов) древнерусские общины, которые существовали в населенных пунктах сельской местности, многие названия которых сохранились до настоящего времени (вервь, город, т.е. огороженный укрепленный населенный пункт, острог, посад, слобода, погост, село, сельцо, деревня, поселок, займище, выселок). Как основообразующие институты раннефеодального общества общины представляли собой самоуправляющиеся, автономные организации, обладающие административно-судебной самостоятельностью. Высшими органами управления общины были сходы населения (мира) - вече, на которых решались важнейшие вопросы их жизни: о войне и мире, о приглашении и изгнании неугодных князей, о принятии законов, избрании должностных лиц и другое. Административно-территориальное устройство, порядок формирования органов местного самоуправления и разделение функций между центральными и местными органами в Новгородской и Псковской феодальных республиках свидетельствуют о наличии там элементов организации местного самоуправления в сельских поселениях на основе территориального принципа. Населенные пункты делились на части, которые назывались концами. Концы делились, в свою очередь, на улицы. В каждом конце действовала система самоуправления, состоящая из вече (народного собрания) и кончанского старосты. Улицы также имели свое вече (собрание) и уличанского старосту. Старосты концов и улиц избирались на вече концов и вече улиц. На местную власть (концы, улицы) законами, утверждаемыми центральной властью (вече республики, а в период между ними - советом господ с участием кончанских старост), возлагались как решение местных вопросов (избирательная функция,

\footnotetext{
${ }^{3}$ Кононов А.М. Местное самоуправление в Российской Федерации. Саратов, 1997.С. 43-44.
}

обустройство вверенных территорий), так и решение государственных задач (административно-судебные функции, сбор налогов). С усилением процессов централизации государственной власти деятельность вече, концов, улиц была прекращена полностью примерно в конце XV века.

Наиболее распространенной формой местного самоуправления в сельских поселениях России средних веков является крестьянское общинное самоуправление, корни которого можно обнаружить в самоуправлении свободных крестьян-общинников периода раннего средневековья. Важнейшие вопросы жизни общины (о форме землепользования, распределении мирского надела по дворам, налогах, круговой поруке, принятии новых членов общины и выполнении повинностей, выборах общинной администрации и другие) обсуждались на сходах - собраниях домохозяев (собрание большой семьи). Решение мира (населения общины), принятое после обсуждения, было обязательным для всех крестьян-общинников. Однако государственную власть в сельской местности осуществляли назначенные лица, которые в своей деятельности практически не контролировались сельскими общинами. Крестьянское общинное самоуправление получило свое развитие в ходе земской реформы Ивана IV Грозного на основе Уставной земской грамоты 1551 года. Основная идея реформы - замена неэффективного института наместничества выборными земскими учреждениями. Земская реформа предусматривала возможность осуществления самоуправления непосредственно проведением сходов, на которых крестьянские общины выбирали должностных лиц местного самоуправления. Представительным органом местного самоуправления являлась земская изба, состоявшая из земского старосты (ее главы), земского дьячка и целовальников, которые избирались из числа наиболее зажиточных посадских людей и государственных (черносошных) крестьян сроком на один-два года. Земские избы содержались на деньги местного самоуправления. В их ведении находились суд, полиция, управление населением и сбор податей. Выборные органы имели широкие полномочия. Контроль за ходом их деятельности осуществлялся в форме заслушивания отчетов и при рассмотрении наиболее важных вопросов крестьянской общины на местных сходах. Здесь мы также наблюдаем территориальный принцип организации сельского местного самоуправления. Позднее демократические начала местного самоуправления в сельских поселениях - выборность органов и относитель- 
ная автономность в организации управления - были вытеснены аппаратно-бюрократическими. ${ }^{4}$

С введением в начале XVII века института воеводства (воевода назначался разрядным приказом через систему утверждения приказа царем и боярской думой) земские органы были практически лишены самостоятельности в решении местных вопросов. Выбираемые крестьянскими общинами в волостях старосты подчинялись назначаемым государством чиновникам и не имели голоса в административных учреждениях, сельские сходы не имели возможности влиять на решение местных вопросов. В этот исторический период и до середины XIX века (время абсолютизма) местное самоуправление в сельских поселениях носило узко сословный характер и его идея, как одного из способов социального управления, отвергалась. Кризис феодально-крепостнической системы, недовольство своим положением крестьян вынудили самодержавную власть ввести элементы самоуправления в селе для государственных крестьян по поселенческому и территориальному принципу. Волостное самоуправление (сход, правление и староста) и сельское (сход и староста) осуществляли ряд полицейских и судебных функций, вели дела по врачебному благоустройству, народному продовольствию, обеспечивали противопожарные мероприятия, проводили сбор податей и выполнение повинностей, прежде всего рекрутской. Вся деятельность государственного крестьянского самоуправления проходила под усиленной опекой специально созданного в 1837 году Министерства государственных имуществ. Крестьянская реформа 1861 года распространила деятельность органов самоуправления государственных крестьян на все сельское общество, основную единицу сельского управления. Теперь сельский сход состоял из всех домохозяев сельского общества. К функциям схода относились: выбор сельских должностных лиц и назначение выборных на волостной сход; вынесение приговоров об удалении из общества его членов и прием новых членов; разрешение семейных разделов и назначение опекунов и попечителей; вопросы пользования землей; ходатайства об общественных нуждах; установление сборов на мирские расходы. Исполнительным органом сельского схода был сельский староста, которому принадлежали общие полицейские функции: за незначительные проступки мог подвергнуть виновного к назначению об-

4 Лаптева Л.Е. Земские учреждения в России. М., 1993. C. 22-31. щественных работ, аресту до двух дней или штрафу. Это был наиболее уважаемый домохозяин, исполнявший свои функции на общественных началах. Сельское общество назначало и других должностных лиц - сельских писарей, сторожей, которые несли службу уже на основе трудового найма. Несколько сельских обществ входили в состав волости. Органами волостного самоуправления были волостные сходы, старшина, управление и суд. Волостной сход организовывался на основе представительства и состоял из выборных по одному от каждых десяти домохозяев. В компетенцию волостного схода входили следующие функции: выбор должностных лиц, выдвижение кандидатов в земские гласные, установление сборов на волостные нужды. Волостной старшина, избранный сходом, был исполнительным органом волостного схода: председательствовал в волостном правлении, которое состояло из всех сельских старост, сборщиков податей и одного или двух заседателей (разрешало вопросы производства расходов из волостных сборов, продажу частного имущества по всякого рода взысканиям, определение и увольнение волостных должностных лиц, служивших по найму); выполнял определенные полицейские функции (мог подвергнуть штрафу или назначению на общественные работы). ${ }^{5}$

Реформирование земского самоуправления XIX века (начало было положено Александром II с утверждения Положения о губернских и уездных земских учреждениях 1864 года, затем регулировалось Положением о земских учреждениях 1890 года; в основе реформы была концепция «общественной» теории) позволило сельским обществам влиять на уездное местное самоуправление через своих представителей. При избрании органов местного самоуправления уездов (земств) избиратели делились на сословных началах на три курии (группы): уездных землевладельцев, городских избирателей и выборных от сельских обществ. Выборы по крестьянской курии были многоступенчатыми. От сельских обществ выбирались представители (только из крестьян) на волостные сходы, из них - выборщики, а из последних - «гласные» (депутаты) в земское (уездное, губернское) собрание. Здесь мы видим официальное признание государством существования общины как исторически сложившегося

${ }^{5}$ Быстренко В.И. История государственного управления и самоуправления в России: Учебное пособие. М., 1997. С. 27. 


\section{Политика и общество 3 (99) • 2013}

факта существования местного самоуправления в сельской местности. Община, писал Л.А. Велихов, имеет право на самостоятельность от центральной власти по своей природе, причем государство не создает общину, а лишь признает ее. ${ }^{6}$ Земское собрание было распорядительным органом. Оно избиралось один раз в три года, собиралось регулярно раз в год, а при чрезвычайных ситуациях - чаще. Председателем земского собрания, как правило, становился предводитель дворянства. Исполнительным органом земского собрания была земская (уездная, губернская) управа (не входила в структуру государственных органов), председателя которого утверждал губернатор (его сословная принадлежность не была ограничена). Деятельность земских учреждений замыкалась на решении местных хозяйственных дел (содействие к предупреждению падежа скота, охрана посевов от истребления саранчой, заведование земскими благотворительными учреждениями, содержание земских путей сообщения, решение вопросов образования и медицины и другое). На практике в связи с недостаточно определенной и разграниченной компетенцией двух уровней местного самоуправления - уездных и губернских земских учреждений - возникали споры, разрешать которые был призван правительствующий Сенат. ${ }^{7}$ Постепенно сфера земской системы местного самоуправления в государственном механизме России стала ограничиваться государственной властью на уровне губернатора. Крестьяне лишились права избирать гласных непосредственно, и они стали назначаться губернатором из числа избранных крестьянами кандидатов. Однако в период роста революционных настроений в начале XX века это право крестьян не только восстановили, но в работе земств по линии решения вопросов столыпинской аграрной реформы появились новые направления деятельности (пропаганда реформы, оказание помощи переселенцам, проведение сельскохозяйственных выставок, создание опытно-показательных станций, содействие сель-

\footnotetext{
${ }^{6}$ Велихов Л.А. Основы городского хозяйства: В 2 ч. Ч. 2: Общее учение о городе, его управлении, финансах и методах хозяйства. М. - Л., 1928. С. 236.

${ }^{7}$ Ефремова Н.Н., Немытина М.В. Местное самоуправление и юстиция в России (1864-1917 гг.) // Государство и право. 1994. № 3. C. 129.
}

скохозяйственному кредиту). Земства расширили географию своего действия и в канун Первой мировой войны действовали в 43 губерниях.

Ученые по-разному оценивают значение земств в России как органов местного самоуправления. К примеру, Н.В. Постовой не считает их органами местного самоуправления ни по составу (представляют не все население, а лишь отдельные классы, и эти классы представлены неравномерно), ни по кругу действий (по сути, являлись административными органами центрального управления). ${ }^{8}$ Однако, безусловно, земства в истории России стали своеобразной школой, через которую прошли многие представители демократического направления, они сыграли большую роль в поднятии культурного уровня сельских поселений, распространении грамотности, доступности медицинского обслуживания деревни. В этот период в России стала формироваться и своя теоретическая концепция местного самоуправления. ${ }^{9}$

В основу деятельности власти в России после 1917 года был положен принцип единства системы советов - органов государственной власти. Идея этой модели социального управления в обществе строилась на том, что в провозглашенном самоуправляемом бесклассовом обществе нового типа государственное управление должно было осуществляться самим народом через систему максимально приближенных к народу органов - советы. В сельских поселениях такими органами являлись местные советы, непосредственно избираемые сельским населением по территориальному принципу. По Конституции РСФСР 1918 года это были сельские советы, волостные советы, а после принятия Конституции СССР 1936 года и в связи с изменением административно-территориального деления страны их представляли сельские советы народных депутатов. При этом демократический характер новой власти виделся в том, что «местные Советы свободно объединяются, на началах демократического централизма, в единую, федеральным союзом скрепленную, общегосударственную Советскую власть Российской Советской республики». ${ }^{10}$ Согласно это-

\footnotetext{
8 Постовой Н.В. Муниципальное право России. М., 1998. C. 62-63.

9 Уваров А.А. Местное самоуправление в России. М., 2006. C. $26-28$.

${ }^{10}$ Ленин В.И. О демократизме и социалистическом характере
} Советской власти. Полн. собр. соч. Т. 36. М., 1962. С. 481. 
му принципу вышестоящие Советы осуществляли руководство нижестоящими (сельскими - районные, районными - областные и т.д.). Они могли отменять противоречащие закону решения нижестоящих советов, которые были им подотчетны и подконтрольны. Сельские советы (избранные населением депутаты) в соответствии со ст. 149 Конституции (Основного Закона) СССР избирали исполнительно-распорядительные органы - исполкомы из числа депутатов, которые проводили в жизнь решения сельского совета и вышестоящих советов. Избиратели давали наказы своим депутатам, за исполнение которых они отчитывались. С целью успешной реализации задач по организации деятельности местных органов власти нового типа на основании постановлений руководящей партии и правительства в сельские поселения готовились и направлялись руководители исполнительных органов сельских советов и руководители новых сельскохозяйственных организаций (колхозов, совхозов, машино-тракторных станций), призванные обеспечивать материально-техническую основу деятельности власти в сельской местности, государством укреплялась материально-техническая база реформируемого сельского хозяйства. ${ }^{11}$ На основании ст.ст. 145-148 Конституции (Основного Закона) СССР местные советы руководили деятельностью подчиненных им органов управления, занимались обеспечением охраны государственного порядка, устанавливали местный бюджет, руководили местным культурным строительством. На территории сельского совета размещались одно или несколько сельскохозяйственных предприятий (колхозов, совхозов) для обеспечения сельскохозяйственного и социального развития территории. Руководители сельского совета, хозяйства, секретарь первичной партийной организации КПСС, которая в соответствии со ст. 6 Конституции (Основного Закона) СССР была руководящей и направляющей силой советского общества (обязательно действовала на территории сельского совета), не предлагались для назначения или избирания без утверждения (согласования) кандидатур в соответствующих вышестоящих органах КПСС. Как правило, они до назначения или избрания проходили специальную подготовку в соответствующих учебных заведениях:

${ }^{11}$ Решения партии и правительства по хозяйственным вопросам. В пяти томах. 1917-1967 гг. Сборник документов за 50 лет. Том 2. 1929-1940 годы. М., 1967. С. 16-19, 74-75. для Омской области это были Советская партийная школа областной партийной организации КПСС, годичные курсы с отрывом от производства при Омском государственном сельскохозяйственном институте имени C.M. Кирова и Новосибирская высшая партийная школа. Как интересный факт необходимо отметить существование научных концепций по развитию сельских территорий, которые находили поддержку в принятии как общегосударственных, так и территориальных программ социально-экономического развития села и позволяли вкладывать в их развитие значительные государственные средства и тем самым создавать привлекательность жизни в сельской местности. ${ }^{12}$ Понятие местного самоуправления в литературе советского периода было заменено понятием социалистического самоуправления. Однако на практике социалистическое самоуправление как качественно новая эффективная форма участия граждан в управлении государственными и общественными делами не соответствовала своей теоретической модели. Местные исполнительные органы оказались в двойном подчинении: 1) местным советам, которые их формировали; и 2) соответствующим органам аппарата вышестоящих советов (ст. 150 Конституции (Основного Закона) СССР). Все это преследовало цель обеспечить необходимую степень централизации государственной власти и, в этой ситуации, приоритетными были не вопросы местного значения сельских поселений, а выполнение директив центра. Практика была такова, что не депутаты, а в большей мере аппарат исполнительных комитетов сельских советов влиял на подготовку и принятие решений местных советов (депутаты для аппарата были, по сути, общественными помощниками). Депутатам сельских советов избиратели давали наказы, но приняты могли быть только те из них, которые заранее были подогнаны под планы и установки, доводимые сверху, либо не требующие больших затрат. Теоретически провозглашенное всевластие советов на практике оказалось проводником воли чиновников и партийно-бюрократической элиты, что, в конечном счете, привело к гибели системы советов в России.

\footnotetext{
12 Заславская Т.И. Теоретические вопросы исследования социально-территориальной структуры советского общества // Социально-территориальная структура города и села: (Опыт типологического анализа) / СО АН СССР. ИЭиОПП. Новосибирск, $1982-154$ с.
} 


\section{Политика и общество 3 (99) • 2013}

Реформы конца 80-х годов прошлого века по внедрению принципа разделения властей привели к введению в стране системы местного самоуправления вместо местных советов. Правовую основу для этого заложил принятый 9 апреля 1990 года Закон СССР «Об общих началах местного самоуправления и местного хозяйства СССР» и соответствующие изменения в Конституцию СССР 1977 года и Конституцию РСФСР 1978 года. Система местного самоуправления в сельских поселениях включала сельские советы народных депутатов в качестве основного звена данной системы, органы территориального общественного самоуправления, местные референдумы, собрания, сходы граждан, иные формы непосредственной демократии. Местное самоуправление в сельских поселениях организовывалось по территориальному принципу и осуществлялось в пределах административно-территориальных единиц сельских округов. В качестве экономической основы местному самоуправлению передавалась коммунальная собственность. В развитие законодательства Союза ССР 6 июля 1991 года был принят Закон РСФСР № 1550-I «О местном самоуправлении в РСФСР», который впервые ввел понятие «муниципальная собственность» вместо «коммунальная собственность», а также принцип ответственности населения за дела местного самоуправления. Закон предусматривал принятие республиками в составе РСФСР собственных законов о местном самоуправлении, а сельскими советами - положений (уставов) о местном самоуправлении на подведомственной им территории. Местное самоуправление строилось на основе сложившейся структуры местной советской государственной власти, сохраняя при этом главенствующую роль сельского совета. В соответствии с законодательством местное самоуправление было выведено из общей системы представительных органов государственной власти. Согласно ст. 9 вышеназванного Закона РСФСР органы государственной власти обязаны были содействовать развитию местного самоуправления на своей территории, принимать меры по сбалансированности бюджетов, оказывать методическую и организационную помощь. Вместе с тем в соответствии с Конституцией РСФСР за Верховным Советом РСФСР сохранялось право руководить местными советами, у вышестоящих советов оставалось право отменить противоречащее законодательству решение местных советов. После известных августовских событий 1991 года законодатель- ством была восстановлена соподчиненность местных администраций вышестоящим исполнительным органам путем назначения всех глав администраций. В дальнейшем происходило сужение сферы влияния представительных органов на дела местного самоуправления. Противоречия в законодательстве, противостояние Президента РСФСР и Верховного Совета РСФСР привели в 1993 году к фактической ликвидации как системы местного самоуправления сельских поселений в России. ${ }^{13}$

С принятием Конституции РФ 12 декабря 1993 года в России были заложены правовые основы современного местного самоуправления. Развитие конституционных принципов организации сельского местного самоуправления мы наблюдаем в принятых законодательных актах субъектов РФ и, главным образом, в Федеральном законе от 28 августа 1995 года № 153-Ф3 «Об общих принципах организации местного самоуправления в Российской Федерации». Местное самоуправление начало строится на основе муниципальных образований (обобщенное наименование городов, поселков, сельских округов, районов, служащих территориальной основой местного самоуправления) с учетом традиций дореволюционного земского права. Однако законодательство фактическое решение вопросов организации местного самоуправления возложило на субъекты РФ. Отсутствие правовых норм, императивно устанавливающих общие требования территориальной организации местного самоуправления, позволило на местах избирать самостоятельный путь решения проблем. В результате, в одних случаях муниципальное устройство полностью совпало с административно-территориальной организацией региона, в других - нет. Некоторые субъекты РФ не имели местного самоуправления в сельской местности на уровне поселения, ограничивая его рамками района. ${ }^{14}$ Не получили развития вопросы разграничения полномочий между местным самоуправлением и государственной властью, что приводило в конечном итоге к финансово-административной зависимости органов местного самоуправления от органов государственного управления. Отсутствовала универсальная территориальная единица, способная стать муниципальным образованием, типичным для

${ }^{13}$ Муниципальное право Российской Федерации / Под ред. проф. Н.С. Бондаря. М., 2002. С. 105-124.

${ }^{14}$ Шугрина Е.С. Муниципальное право. М., 2004. С.18-19. 
всей страны с целью обеспечить конституционное положение об осуществлении местного самоуправления на всей территории.

На основе анализа развития местного самоуправления в России Е.М. Ковешников пришел к следующим выводам, важным и актуальным, на его взгляд, в условиях современного развития России: 1) разделение местного самоуправления на два типа: городское и земское. В рамках земского самоуправления существовали: волостное и сельское (крестьянское); уездное; губернское; 2) существование на местном уровне различных видов местного самоуправления, в том числе производственного, купеческого, студенческого и другого; 3) функционирование (на определенных этапах исторического развития России) самоуправленческих структур на общероссийском уровне; 4) оптимальное сочетание централизованного государственного управления с децентрализацией управления на местах; 5) выполнение местными органами широкого круга полномочий; 6) установление государственного контроля за деятельностью органов и должностных лиц местного самоуправления; 7) тесная взаимосвязь реформ государственного управления с проведением земских и городских реформ; 8) зависимость местного самоуправления от государственной политики, в т.ч. от эффективного правового регулирования общественных отношений, возникающих на местном уровне. ${ }^{15}$

Приведенный выше анализ нормативных актов, научной литературы и исторических фактов позволяют сделать в рамках поставленных задач исследования следующие выводы о местном самоуправлении в сельских поселениях России до этапа современных реформ, наступивших с принятием Федерального закона № 131-Ф3 2003 года: 1) в нормативно-правовом регулировании местного самоуправления сельских поселений обнаруживается: а) сочетание общественных и, в большей мере, государственных начал и б) сохранение и возобновление действовавших ранее муниципально-правовых норм, признание их роли в новой общественной ситуации (подчеркивает их муниципально-правовую преемственность); 2) территориальная организация сельского местного самоуправления строилась по поселенческому или территориальному принципу; 3) существование местного самоуправления в сельских поселениях исторически обуслов-

${ }^{15}$ Ковешников Е.M. Государство и местное самоуправление в России: теоретико - правовые основы взаимодействия. М., 2002. C. 105-106. лено необходимостью обеспечения децентрализации государственного управления и эффективного решения жизненно важных для населения местных задач; 4) государство в периоды реформирования местного самоуправления с целью успешного решения задач предусматривало правовые меры по подготовке и направлению кадров для исполнительных органов и хозяйствующих субъектов сельских поселений, укреплению материально-технической базы сельскохозяйственных организаций.

Местное самоуправление в сельских поселениях за время своего развития не имело признака внешней самостоятельности - независимости от других властей в пределах своей компетенции, подкрепленной имущественным, организационным и финансовым обеспечением. Любые значительные вопросы местного значения, даже отнесенные к компетенции местного общества, будь то вопросы социальной сферы или сферы сельского хозяйства, могли решаться только при помощи органов государственной власти или органов местного самоуправления иного уровня. В то же время власть сельского местного самоуправления имеет свою собственную социальную природу и не тождественна государственной власти, так как наряду с государственными задачами всегда решала местные вопросы. В решении вопросов местного значения она, в какой-то мере, зачастую противостояла государству. Чрезмерная централизация управления, имевшая место в государстве, не способствовала формированию местного самоуправления, отвечающего запросам населения. Реформы сельского местного самоуправления не доводились до конца ввиду отсутствия демократических традиций, правовых механизмов, обеспечивающих исполнение законодательства на местном уровне. На практике администрации всех уровней власти хотели видеть в местном самоуправлении сельских поселений только совещательные, а не властные органы, как некое дополнение к администрации.

Таким образом, местное самоуправление сельских поселений имеет особенности в системе местного самоуправления РФ, которые мы находим как в законодательстве, так и практике осуществления местного самоуправления. Это, в свою очередь, предполагает научное определение понятия и сущности местного самоуправления сельских поселений, учет особенностей сельских поселений в современных условиях (на этапе реализации социально-экономической политики России, направленной на устойчивое комплексное развитие сельских территорий) при правовом регули- 


\section{Политика и общество 3 (99) • 2013}

ровании сельской жизни (комплекса общественных отношений сельских поселений - экономических, социальных, властных, природно-экологических и историко-культурных, в т.ч. возникающих при осуществлении деятельности органов государственной власти и местного самоуправления в пределах своей компетенции).

\section{Библиография:}

1. Костюков А.Н. Муниципальное право как отрасль российского права: Монография. М.:, 2003.

2. Данилевский Н.Я. Россия и Европа. М., 1991.

3. Кононов А.М. Местное самоуправление в Российской Федерации. Саратов, 1997.

4. Лаптева Л.Е. Земские учреждения в России. M., 1993.

5. Быстренко В.И. История государственного управления и самоуправления в России: Учебное пособие. М., 1997.

6. Велихов Л.А. Основы городского хозяйства: В 2 ч. Ч. 2: Общее учение о городе, его управлении, финансах и методах хозяйства. М. - Л., 1928.

7. Ефремова Н.Н., Немытина М.В. Местное самоуправление и юстиция в России (1864-1917 гг.) // Государство и право. 1994. № 3.

8. Постовой Н.В. Муниципальное право России. М., 1998.

9. Уваров А.А. Местное самоуправление в России. M., 2006.

10. Ленин В.И. О демократизме и социалистическом характере Советской власти. Полн. собр. соч. Т. 36. М., 1962.

11. Решения партии и правительства по хозяйственным вопросам. В пяти томах. 1917-1967 гг. Сборник документов за 50 лет. Том 2. 1929-1940 годы. М., 1967.

12. Заславская Т.И. Теоретические вопросы исследования социально-территориальной структуры советского общества // Социально-территориальная структура города и села: (Опыт типологического анализа) / СО АН СССР. ИЭиОПП. Новосибирск, 1982.
13. Муниципальное право Российской Федерации / Под ред. проф. Н.С. Бондаря. М., 2002.

14. Шугрина Е.С. Муниципальное право. М., 2004.

15. Ковешников Е.М. Государство и местное самоуправление в России: теоретико - правовые основы взаимодействия. М., 2002.

\section{References (transliteration):}

1. Kostyukov A.N. Munitsipal'noe pravo kak otrasl' rossiyskogo prava: Monografiya. M.:, 2003.

2. Danilevskiy N.Ya. Rossiya i Evropa. M., 1991.

3. Kononov A.M. Mestnoe samoupravlenie v Rossiyskoy Federatsii. Saratov, 1997.

4. Lapteva L.E. Zemskie uchrezhdeniya v Rossii. M., 1993.

5. Bystrenko V.I. Istoriya gosudarstvennogo upravleniya i samoupravleniya $\mathrm{v}$ Rossii: Uchebnoe posobie. M., 1997.

6. Velikhov L.A. Osnovy gorodskogo khozyaystva: V 2 ch. Ch. 2: Obshchee uchenie o gorode, ego upravlenii, finansakh i metodakh khozyaystva. M. - L., 1928.

7. Efremova N.N., Nemytina M.V. Mestnoe samoupravlenie i yustitsiya v Rossii (1864-1917 gg.) // Gosudarstvo i pravo. 1994. № 3.

8. Postovoy N.V. Munitsipal'noe pravo Rossii. M., 1998.

9. Uvarov A.A. Mestnoe samoupravlenie v Rossii. M., 2006 .

10. Lenin V.I. O demokratizme i sotsialisticheskom kharaktere Sovetskoy vlasti. Poln. sobr. soch. T. 36. M., 1962.

11. Zaslavskaya T.I. Teoreticheskie voprosy issledovaniya sotsial'no-territorial'noy struktury sovetskogo obshchestva // Sotsial'no-territorial'naya struktura goroda i sela: (Opyt tipologicheskogo analiza) / SO AN SSSR. IEiOPP. Novosibirsk, 1982.

12. Munitsipal'noe pravo Rossiyskoy Federatsii / Pod red. prof. N.S. Bondarya. M., 2002.

13. Shugrina E.S. Munitsipal'noe pravo. M., 2004.

14. Koveshnikov E.M. Gosudarstvo i mestnoe samoupravlenie v Rossii: teoretiko - pravovye osnovy vzaimodeystviya. M., 2002. 